\title{
Foraging ecology of the Cook's petrel Pterodroma cookii during the austral breeding season: a comparison of its two populations
}

\author{
M. J. Rayner ${ }^{1, *}$, M. E. Hauber ${ }^{1}$, M. N. Clout ${ }^{1}$, D. S. Seldon ${ }^{1}$, S. Van Dijken ${ }^{1}$, S. Bury ${ }^{2}$, \\ R. A. Phillips ${ }^{3}$ \\ ${ }^{1}$ School of Biological Sciences, University of Auckland, Private Bag 92019, Auckland 1142, New Zealand \\ ${ }^{2}$ National Institute of Water and Atmospheric Research, PO Box 14-901, Kilbernie, Wellington 6011, New Zealand \\ ${ }^{3}$ British Antarctic Survey, Natural Environment Research Council, High Cross, Madingley Road, Cambridge CB3 0ET, UK
}

\begin{abstract}
This study examined divergence in the foraging distribution, at-sea behaviour and provisioning strategies of a small procellarid, the Cook's petrel Pterodroma cookii, during chick-rearing at 2 islands off New Zealand, separated latitudinally by $\sim 1000 \mathrm{~km}$. There was little overlap in foraging distribution between adults from Little Barrier Island (LBI), which ranged to the west into the Northern Tasman Sea and east into the Pacific Ocean, and conspecifics from Codfish Island (CDF), which foraged west of the South Island in the south Tasman Sea in association with the subtropical convergence zone. Although birds from CDF ranged further than those from LBI, there was no difference in mean foraging trip duration. Cook's petrels from CDF foraged over deeper, cooler water, with higher primary productivity, than conspecifics from LBI. At-sea behaviour also differed: adults from LBI spent less time in flight, and showed less variation in total flight time per day. Overall, Cook's petrels spend much more time in flight than albatrosses, and approximately the same amounts of time on the water during the night as during the day, suggesting a high portion of nocturnal foraging. Dive depths did not differ between colonies but were greater than expected for a gadfly petrel. Stable isotope signatures of blood indicated population-specific diets, and suggested that birds from LBI primarily consume cephalopods and fish, whereas those from CDF eat more crustaceans. Chicks at $\mathrm{CDF}$ received more food. These results suggest a broad divergence in foraging strategies between geographically well-separated colonies in response to regional differences in oceanography.
\end{abstract}

KEY WORDS: Foraging distribution · Geolocation loggers · Stable isotopes · Subtropical convergence Gadfly petrel

\section{INTRODUCTION}

Early land-based studies on ecological competition and overlap in seabird communities considered that asynchrony in breeding timetables played a role in staggering peak demand for shared prey resources. Yet, in the absence of some means of tracking birds at sea, those studies were unable to assess the importance of spatial and behavioural segregation at sea (Brooke 2004). Since then, the development of lightweight satellite and geolocation tracking technologies has provided opportunities for examining niche overlap in seabirds (Weimerskirch et al. 1993, 1997, Phillips et al. 2006).

In particular, studies during the breeding season, when adults are amenable for short-term deployment and retrieval of tracking devices, have provided valuable insights into inter- and intraspecific behavioural flexibility and specialisation (Phillips et al. 2005, Phalan et al. 2007). Analyses to date suggest significant spatial segregation of conspecifics when colonies are 10s to 100s of km apart (Ainley et al. 2003, 2004). How- 
ever, there have been relatively few studies of highly pelagic species from more widely separated populations, where there is nonetheless the potential for some overlap and interaction at sea. Such comparisons are particularly interesting given the potential for genetic isolation between populations, as most seabirds display a high degree of natal philopatry (Warham 1996). In addition, the high degree of behavioural flexibility of adults may also lead to divergence in foraging strategies, particularly between distant colonies in dissimilar oceanographic domains.

Until recently, owing to the relatively large size of the available technology, detailed studies on the movements of pelagic seabirds had been restricted to medium to large species to which attachment of equipment was feasible without impacting the animal's behaviour (Weimerskirch et al. 1993, 1997, Stahl \& Sagar 2000a,b). Information on the distribution and behaviour of smaller species $(<300 \mathrm{~g})$ at sea was therefore restricted to band recoveries (Patterson \& Hunter 2000) and shipboard observations (Bartle et al. 1990). However, advances in lightweight global location sensors (geolocation loggers), which record the approximate geographic location of animals at sea using information on light intensity, now present a unique opportunity to study variation in the at-sea behaviour of these smaller seabirds in unprecedented detail, without any apparent deleterious effects (Rayner 2007).

Cook's petrel Pterodroma cookii (200 g) is one of a group of 10 small, highly pelagic petrel taxa often placed in the subgenus cookilaria (Onley \& Scofield 2007). Cook's petrels qualify as 'endangered' under the International Union for Conservation of Nature's (IUCN) criteria, and are restricted to the Pacific Ocean, where they breed in the north of the New Zealand archipelago on Little Barrier Island (LBI) and Great Barrier Island (Imber et al. 2003, Rayner et al. 2007a) and, $1000 \mathrm{~km}$ to the south, on Codfish Island (CDF) (Rayner et al. 2008). Between these distant colonies, the species was once widespread on the New Zealand mainland (Imber et al. 2003). There are no published tracking studies for any of the 39 gadfly petrel species (Pterodroma spp.) (Brooke 2004).

The nonbreeding range of Cook's petrels has been inferred from at-sea observations to involve a transequatorial migration to key wintering areas in the east Pacific Ocean, particularly offshore of western Mexico and California, and in the temperate and subarctic waters of the central north Pacific (Bartle et al. 1990). In turn, during breeding, Cook's petrels are assumed to be restricted to waters around New Zealand, but nothing is known about potential foraging ranges. There are morphological differences between the northern and southern populations, and a strong de- gree of breeding asynchrony; the LBI population breeds ca. 1 mo earlier than the CDF population, suggesting a considerable degree of behavioural and perhaps genetic isolation (Imber et al. 2003).

The aim of the present study was to combine data on movements, activity patterns and dive depth with information on foraging from stable isotope signatures and provisioning rates and meal sizes delivered to chicks to characterise and evaluate differences in the foraging ecology of Cook's petrel breeding at 2 distant colonies, LBI and CDF, during the austral summer. A key prediction of this investigation was that environmental differences in resource availability, resulting from the broad latitudinal separation of these islands, would be reflected in the divergence of the distribution, diet and behaviour of adult Cook's petrel at sea.

\section{MATERIALS AND METHODS}

Study sites. This study was carried out on Cook's petrel in the austral summer of 2006-2007 on LBI $\left(36^{\circ} 11^{\prime} \mathrm{S}, 175^{\circ} 04^{\prime} \mathrm{E}\right)$ and $\mathrm{CDF}\left(46^{\circ} 11^{\prime} \mathrm{S}, 167^{\circ} 38^{\prime} \mathrm{E}\right)$, New Zealand. Work was conducted for 2 wk during the first month of chick-rearing at each study location. Given the 1 mo asynchrony in the breeding timetable between the 2 populations (Imber et al. 2003), the present study was conducted at LBI between mid-January and early February and at CDF between mid- and late February to include comparable stages of the breeding cycle between birds breeding at either of the 2 study sites.

At each colony, 10 active breeding burrows were selected from burrows with previously installed removable lids which permitted easy access to nest chambers (Rayner et al. 2007b). An additional 10 active breeding burrows were used as controls for the effect of tracker attachment on foraging and breeding behaviour. Adult attendance at these burrows was monitored using stick gates at the burrow entrance (a small wall of upright twigs that would be knocked down when a bird enters). At the 10 burrows with birds tracked, chick tarsus length was also measured to the nearest $\mathrm{mm}$ using dial callipers at the start of the study, and chick mass monitored daily by the weighing of chicks between 11:00 and 13:00 h. Chicks were virtually always fed between 22:00 and 02:00 h. Chicks that gained mass over a $24 \mathrm{~h}$ period were assumed to have been fed, and the mass of the meal(s) was estimated as the sum of the daily mass increment, and $50 \%$ of the mean $24 \mathrm{~h}$ weight loss of all unfed chicks, as chicks would usually have been fed $12 \mathrm{~h}$ earlier (Hamer et al. 1997, Rayner 2007). Foraging trip duration to the nearest day was recorded for all banded birds and all study burrows (at both colonies) were visited by no more 
than 1 adult night ${ }^{-1}$ as ascertained by trapdoors (see next paragraph).

Logger deployment, data processing and remote sensing data. Combined global location sensor and immersion loggers (GLS-I; Afanasyev 2004) weighing $2.4 \mathrm{~g}$ were deployed on 1 adult Cook's petrel (for a single foraging trip) from 10 burrows at each study site. Dummy loggers weighing $4.5 \mathrm{~g}$ had been trialled previously on Cook's petrels and were shown not to alter foraging trip durations (Rayner 2007). All breeding adults from study burrows had been banded and sexed in the previous breeding season through DNA analysis of blood samples taken from the tarsal vein using standard PCR methods (Fridolfsson \& Ellegren 1999) and, as a result, loggers were deployed on an even sex ratio (5 males and 5 females) from each population ( 1 bird tracked per pair breeding in each burrow). Adults were captured at night after returning to feed chicks using trapdoors. These were manufactured from $120 \mathrm{~mm}$ drain pipe and Perspex plastic, and allowed entry only. Burrows were checked regularly, and the maximum time that a bird would have been trapped was 1 to $2 \mathrm{~h}$. Loggers were attached by a cable tie to a Darvic PVC plastic leg band fitted to the tarsus (total attachment weight $3 \mathrm{~g}$ or $\sim 1.5 \%$ of body weight), and retrieved after single foraging trips using the same burrow gate system.

The loggers measured light level every minute and logged its maximum intensity every $10 \mathrm{~min}$. Light data were processed using Multitrace software (Jensen Software Systems) and locations $\left(2 \mathrm{~d}^{-1}\right)$ were estimated (Phillips et al. 2004). Sunrise and sunset times were identified based on light curve thresholds, with longitude calculated from the time of local midday relative to Greenwich Mean Time, and latitude calculated from day length. Locations with interruptions around sunset and sunrise were screened from the data set. Based on concurrent deployment of GLS loggers and satellite transmitters in black-browed albatrosses Thalassarche melanophrys, locations were considered to have a mean accuracy \pm SD of around $186 \pm 114 \mathrm{~km}$ (Phillips et al. 2004).

The foraging distribution of each Cook's petrel population was established by generating kernel density maps in a Lambert Equal-Area Azimuthal (South Pole) projection with the Spatial Analyst extension of Arcview 9.0 (ESRI), using a search radius of $200 \mathrm{~km}$ and cell size of $50 \mathrm{~km}$ (Phillips et al. 2005, 2007). Kernel density maps were overlaid on bathymetry (obtained from www.ngdc.noaa.gov/mgg/gdas/gd_designagrid. html) and monthly composites of remotely sensed seasurface characteristics. These were sea-surface temperature (SST) in ${ }^{\circ} \mathrm{C}$ and chlorophyll a ( $\mathrm{chl}$ a) concentration in $\mathrm{mg} \mathrm{chl} \mathrm{m}^{-3}$ (which is a proxy for oceanic primary production) as Aqua MODIS-mapped products down- loaded from http://web.science.oregonstate.edu/ocean. productivity (Behrenfeld \& Falkowski 1997). Monthly composites from January and February were used for the LBI and CDF studies respectively, with all map overlays having a $9 \mathrm{~km}$ resolution. For further analyses, the average value for the 3 environmental variables (bathymetry, SST and chl a) was extracted for all $50 \mathrm{~km}$ kernel cells for each Cook's petrel population using Arcview's ArcGrid extension and FOCALMEAN function. The maximum range achieved by each bird was calculated in ArcMap by measuring the great circle distance between the colony and the furthest location (Phillips et al. 2007).

Foraging behaviour. The loggers also tested for saltwater immersion every $3 \mathrm{~s}$ and logged a value every 10 min ranging from 0 (completely dry) to 200 (completely wet) (Phalan et al. 2007, Phillips et al. 2007). These data were matched against the time of civil twilight (when the sun is $6^{\circ}$ below the horizon) and used to calculate the percentage of time spent on the water during daylight and darkness (Phillips et al. 2007). Cook's petrels often return to breeding colonies during daylight and spend extended periods on the water before coming ashore in darkness (M. J. Rayner pers. obs.). Visual examination of immersion data from loggers confirmed this conclusion, with all birds showing extended periods of immersion prior to darkness on the day of return. The final day of activity data for each tracked bird was therefore excluded from analysis to gain an unbiased reflection of foraging activity patterns of birds at sea.

To quantify dive depths attained by Cook's petrel, capillary-tube dive depth gauges were attached to the mate of Cook's petrels tracked with GLS loggers using the same capture and recapture protocols. Gauges were attached to the underside of the 3 central rectrices using thin strips of cloth duct tape (Sellotape) with the open end facing towards the end of the retrices, and consisted of a $10 \mathrm{~cm}$ length of $1 \mathrm{~mm}$ internal diameter $(2 \mathrm{~mm}$ external diameter, total weight $1 \mathrm{~g}$ or $0.5 \%$ of body weight) clear capillary tubing, coated internally with a thin layer of icing sugar and heat sealed at one end (Burger \& Wilson 1988, Prince \& Jones 1992). Maximum dive depth was calculated as per Burger \& Wilson (1988) using the formula $d=$ $10.08\left(L_{\mathrm{s}} / L_{\mathrm{d}}-1\right)$, where $d$ is the maximum dive depth in $\mathrm{m}, 10.08 \mathrm{~m}$ the seawater depth required for a $1 \mathrm{~atm}$ change in pressure, $L_{\mathrm{s}}$ the length of the air column in the capillary tube prior to deployment and $L_{\mathrm{d}}$ the length of the air column, in the same length unit as $L_{\mathrm{s}}$ after deployment.

Stable isotope ratios. Stable isotope ratios of blood reflect those of the prey consumed by an animal over a period of days to weeks (Hobson 1993). Measures of $\delta^{13} \mathrm{C}$ (the ${ }^{13} \mathrm{C}:{ }^{15} \mathrm{C}$ ratio) and $\delta^{15} \mathrm{~N}$ (the ${ }^{15} \mathrm{~N}:{ }^{14} \mathrm{~N}$ ratio) are 
particularly useful in studies of marine organisms, as $\delta^{13} \mathrm{C}$ provides spatial information (on latitudinal distribution at sea and reliance on benthic vs. pelagic, and inshore vs. offshore diet), whereas $\delta^{15} \mathrm{~N}$ increases in a stepwise manner by $\sim 3$ to $5 \%$ with each trophic level and, given information on prey baseline levels, can provide information on the type of prey consumed (Hobson et al. 1994, Bearhop et al. 2002). To provide an interpopulation comparison of isotope ratios, blood samples $(0.05 \mathrm{ml})$ were collected from the tarsal veins of adult Cook's petrels returning from foraging trips with geolocators and dive depth gauges attached. Samples were stored in $70 \%$ ethanol, with the ethanol removed prior to analysis by heating the samples in an incubator for $12 \mathrm{~h}$ at $50^{\circ} \mathrm{C}$. All stable isotope analyses were carried out on a Delta ${ }^{\text {Plus }}$ (Thermo-Finnigan) continuous flow isotope ratio mass spectrometer. Solid blood samples were prepared in tin boats and combusted in an NA $1500 \mathrm{~N}$ (Fisons Instruments) elemental analyser combustion furnace at $1020^{\circ} \mathrm{C}$ in a flow of $\mathrm{O}_{2}$ and $\mathrm{He}$ carrier gas. Oxides of nitrogen were converted to $\mathrm{N}_{2}$ gas in a reduction furnace at $640^{\circ} \mathrm{C} . \mathrm{N}_{2}$ and $\mathrm{CO}_{2}$ gases were separated on a Porapak Q gas chromatograph column before being introduced to the mass spectrometer detector via an open split Conflo II interface (Thermo-Finnigan). $\mathrm{CO}_{2}$ and $\mathrm{N}_{2}$ reference gas standards were introduced to the mass spectrometer with every sample analysis. ISODAT (Thermo-Finnigan) software was used to calculate $\delta^{15} \mathrm{~N}$ values against atmospheric air, and $\delta^{13} \mathrm{C}$ values against the $\mathrm{CO}_{2}$ reference gas relative to the international Pee Dee Belemnite (PDB) standard, correcting for ${ }^{17} \mathrm{O}$. Measurement precision was estimated to be 0.1 to $0.5 \%$ for $\delta^{15} \mathrm{~N}$ and 0.3 to $0.4 \%$ for $\delta^{13} \mathrm{C}$.

Analyses. Differences in initial chick tarsus lengths and patterns of parental burrow attendance (mean visits night ${ }^{-1}$ over the entire study period) between control and tracked burrows were tested using Student's $t$-tests at each location. Comparisons of foraging characteristics (trip duration, chick meal mass, percentage time on water during daylight and darkness, maximum range and dive depth), and stable isotope ratios, were made using Student's $t$-tests with arcsine and log transformations where appropriate to normalise data between islands. We also quantified sex-specific data on all aspects of adult behaviours.

Mean foraging trip duration was also compared between adults at LBI in 2005-2006 (Rayner 2007) and 2006-2007 (the present study), and at CDF in 20062007 (the present study). A bimodal foraging strategy (interspersed short and long trips) is a recognised foraging strategy in procellariiform seabirds (Weimerskirch et al. 1994, Cherel et al. 2002b), and so we applied a Shapiro-Wilk test to assess whether the distribution of foraging trip durations from either site departed from a unimodal normal distribution. Meal mass was compared between populations, using the mean value for each chick during the entire $14 \mathrm{~d}$ study to avoid pseudo-replication. Logistic regression was used to compare environmental predictors of at-sea locations, calculated within kernel cells, between the $60 \%$ kernels for birds from each breeding site. The $60 \%$ kernel distributions were used to account for low accuracy of positions acquired by GLS loggers (Phillips et al. 2007) which have a mean error of $186 \pm 114 \mathrm{~km}$ (Phillips et al. 2004). Natural-log or square-root transformations were used to normalise the data and 3-way interactions included in the model as a result of correlations between the 3 predictors. The strength of spatial cross-correlation between the kernel density surface and each environmental predictor was calculated using the CORRELATION function in the ArcGrid extension to Arcview. Unless otherwise stated, all analyses were conducted using JMP 5.1 (SAS Institute) with a threshold of significance set at $\alpha=0.05$, and were 2 -tailed tests. Data are shown as mean $\pm \mathrm{SD}$.

\section{RESULTS}

There was no difference in the average initial tarsus length of chicks from LBI $(28.32 \pm 3.07 \mathrm{~mm})$ and CDF $(26.73 \pm 2.59 \mathrm{~mm})\left(t\right.$-test: $\left.t_{18}=1.25, \mathrm{p}=0.88\right)$, confirming chicks were of similar ages and comparable developmental stages at the 2 colonies at the start of the respective study periods.

\section{Device effects}

Eight of the 10 breeding adults fitted with loggers at LBI were recaptured by the end of the 2 wk study period and the loggers retrieved. Of these, 1 logger failed to download. Loggers from the missing 2 birds were retrieved in the subsequent 2007-2008 breeding season; these birds appeared in good breeding condition and were found incubating eggs. All 10 breeding adults fitted with loggers at CDF were recaptured and the loggers retrieved. Over the $14 \mathrm{~d}$ study period there was no significant difference in the feeding frequency at tracked $(n=10)$ and control $(n=10)$ burrows on LBI $\left(0.28 \pm 0.08\right.$ and $0.32 \pm 0.08$ visits night $^{-1}$, respectively; $t$-test: $\left.t_{18}=-1.44, \mathrm{p}=0.18\right)$ and $\operatorname{CDF}(0.38 \pm 0.12$ and $0.38 \pm 0.03$ visits night ${ }^{-1}$, respectively; $t$-test: $t_{18}=-0.79$, $p=0.44$ ). There was also no significant difference in foraging trip duration between birds fitted with loggers $(1.5 \%$ of body weight) compared with birds fitted with depth gauges only ( $0.5 \%$ of body weight) at LBI $\left(5.0 \pm 2.7\right.$ and $6.3 \pm 2.7 \mathrm{~d}$, respectively; $t$-test: $t_{14}=$ $-0.99, \mathrm{p}=0.19)$ or $\mathrm{CDF}(4.6 \pm 1.4$ and $5.5 \pm 1.5 \mathrm{~d}$, 
respectively; $t$-test: $t_{16}=1.34, \mathrm{p}=0.20$ ). Fledging data were not collected for the CDF population because of limited access to the island for seabird research, while all chicks from study and control burrows on LBI fledged successfully after completion of the study, as determined by subsequent burrow inspections.

\section{Foraging duration, distribution and environment}

Foraging trips lasted for 2 to $11 \mathrm{~d}$ at LBI and 2 to $12 \mathrm{~d}$ at CDF (Fig. 1). There was no significant difference in mean foraging trip duration between birds at LBI in 2006-2007 (5.6 \pm 2.8 d, n = 16) compared with 2005$2006\left(6.0 \pm 3.1 \mathrm{~d}, \mathrm{n}=17\right.$; Rayner 2007) ( $t$-test: $t_{31}=$ $-0.23, p=0.42$ ), nor between these pooled data (LBI: overall mean $5.9 \pm 3.1 \mathrm{~d}, \mathrm{n}=33$ ) and the foraging trip durations of CDF birds in 2006-2007 (5.0 $\pm 3.0 \mathrm{~d}, \mathrm{n}=$ 17) ( $t$-test: $t_{48}=-0.09, \mathrm{p}=0.49$; Fig. 1 ). Sex-specific data were unavailable for the 2005-2006 season on LBI; in 2006-2007, there was no effect of sex on foraging trip duration at LBI (females: $6.3 \pm 3.1 \mathrm{~d}$, males: $4.3 \pm 2.8 \mathrm{~d}$; $t$-test: $t_{13}=0.93, \mathrm{p}=0.37$ ) and CDF (females: $4.9 \pm 1.4 \mathrm{~d}$, males: $5.3 \pm 1.2 \mathrm{~d}$; $t$-test: $t_{11}=0.35, \mathrm{p}=0.73$ ) (Table 1 ). Duration of adult foraging trips from LBI was not significantly different from a unimodal normal distribution in the 2005-2006 (Shapiro-Wilk test: $W=0.95, \mathrm{p}=$ 0.43, mode $=3 \mathrm{~d}$ ) and 2006-2007 seasons (Shapiro-

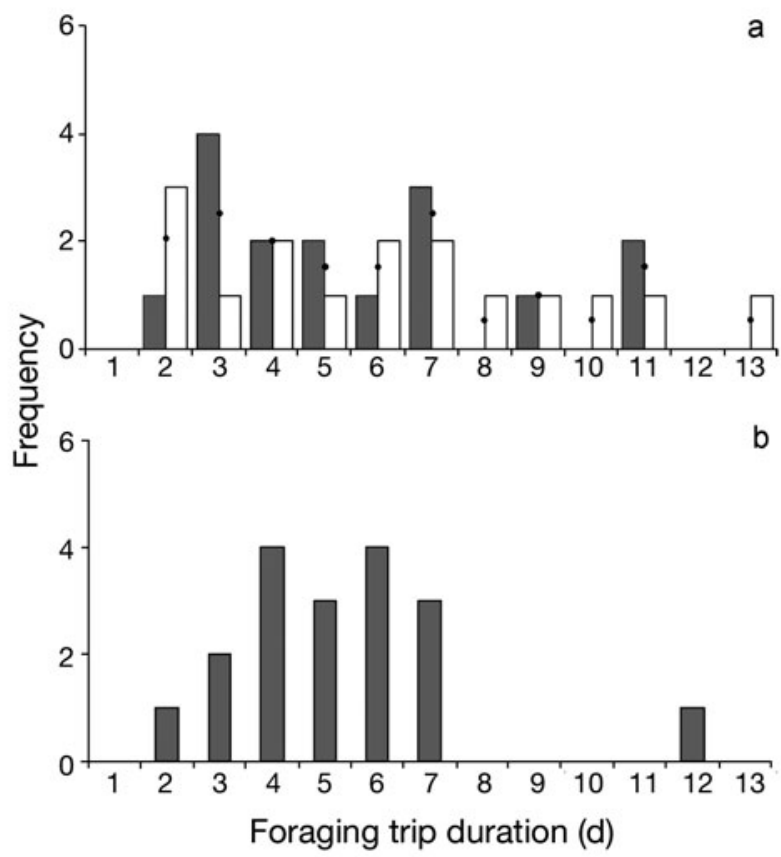

Fig. 1. Frequency of foraging trips of different durations by individual adult Cook's petrel from (a) Little Barrier Island in January 2006 (white, $\mathrm{n}=16$, data from Rayner 2007) and January 2007 (grey, $\mathrm{n}=16$ ), and average values for 2006 and 2007 (black points), and (b) Codfish Island in February $2007(\mathrm{n}=17)$
Wilk test: $W=0.90, \mathrm{p}=0.08$, mode $=2 \mathrm{~d}$ ), but there was a pattern suggesting non-normality for the combined data set (Shapiro-Wilk test: $W=0.93, \mathrm{p}=0.06$, mode $=$ 3 d) (Fig. 1a). The duration of foraging trips from CDF was not normally distributed (Shapiro-Wilk test: $W=$ $0.84, \mathrm{p}=0.006$ ) as a result of a single bird that engaged in a $12 \mathrm{~d}$ foraging trip (Fig. 1b). However, the overall pattern of this distribution is consistent with a single mode at $4 \mathrm{~d}$ if this outlier is excluded (Shapiro-Wilk test: $W=0.96, \mathrm{p}=0.47$ ).

A total of 51 and 114 logger locations were obtained from the 7 and 10 birds tracked, respectively, from LBI and CDF, of which 12 and $10 \%$ were excluded because of light-level interference (interruptions in light data making position estimates unreliable; Phillips et al. 2004), resulting in 45 and 105 validated locations for each of the 2 populations. Cook's petrels from LBI were distributed east and west of the North Island of New Zealand $\left(164^{\circ} \mathrm{E}\right.$ to $\left.178^{\circ} \mathrm{W}\right)$ with core areas $(20 \%$ kernels) in the region of the colony, to the west over the Challenger Plateau and Lord Howe Rise, and to the east over the Hikurangi Trough and Plateau (Fig. 2). By comparison, birds tracked from CDF were distributed to the west of the South Island in the Tasman Sea to within $500 \mathrm{~km}$ of Tasmania $\left(152^{\circ}\right.$ to $\left.169^{\circ} \mathrm{E}\right)$ with core areas in the Tasman Basin (Fig. 2). There was overlap in the distributions of birds from the 2 populations only in the region of the Challenger Plateau to the west of the North Island, which represented only a small proportion of the range in either case (Fig. 2). At the intrapopulation level, there was a great deal of overlap between individuals from LBI and, although small sample sizes permit only speculation, it appears that males $(\mathrm{n}=4$ ) had larger foraging ranges than females $(\mathrm{n}=3$ ) (Fig. 3, Table 1). In contrast, there was no obvious relationship between sex and distribution of birds from CDF (Fig. 4).

The environmental correlates of Cook's petrel foraging distributions (60\% kernels) are shown in Fig. 5. LBI Cook's petrel foraged over shallower water than CDF Cook's petrel $(1700 \pm 74 \mathrm{~m}$ vs. $3891 \pm 144 \mathrm{~m}$, respectively; Wald's $\chi^{2}=218$, df $=1, p \leq 0.001$; Fig. 5). The distribution of birds from LBI was weakly correlated with water depth, whereas that of birds from CDF showed a stronger relationship ( $r=0.15)$ (Fig. 5). SST values of the relative foraging distributions were higher for birds from the LBI than from the CDF population $\left(18.6 \pm 0.1^{\circ} \mathrm{C}\right.$ vs. $15.8 \pm 0.1^{\circ} \mathrm{C}$, respectively; Wald's $\chi^{2}=20$, df $=1, \mathrm{p} \leq 0.001$; Fig. 5) although neither distribution was strongly correlated with SST gradient (LBI: $r=0.01, \mathrm{CDF}: \mathrm{r}=0.05$ ) (Fig. 5). Chl $a$ concentration was twice as high within the foraging distribution birds from CDF $\left(0.26 \pm 0.01 \mathrm{mg} \mathrm{m}^{-3}\right)$ compared with LBI $\left(0.49 \pm 0.02 \mathrm{mg} \mathrm{m}^{-3}\right)$ (Wald's $\chi^{2}=28$, $\mathrm{df}=1, \mathrm{p}<0.001$; Fig. 5). Although the LBI distribution 
Table 1. Sex-specific activity data for Cook's petrel from Little Barrier Island (LBI) and Codfish Island (CDF). Values are mean $\pm \mathrm{SD}$ (range) with sample sizes included in italicised subscript

\begin{tabular}{|c|c|c|c|c|c|c|c|c|c|}
\hline \multirow[t]{2}{*}{ Sex } & \multirow{2}{*}{$\begin{array}{l}\text { Duration } \\
\text { (d) }\end{array}$} & \multirow{2}{*}{$\begin{array}{l}\text { Max. range } \\
(\mathrm{km})\end{array}$} & \multicolumn{3}{|c|}{ — Time on water } & \multicolumn{3}{|c|}{ C Coefficient of variation -} & \multirow{2}{*}{$\begin{array}{l}\text { Dive depth } \\
\text { (m) }\end{array}$} \\
\hline & & & Darkness & Daylight & Total & Darkness & Daylight & Total & \\
\hline \multicolumn{10}{|l|}{ LBI } \\
\hline Female & $\begin{array}{c}6.3 \pm 3.1 \\
(3-11)_{8}\end{array}$ & $\begin{array}{c}221 \pm 31 \\
(195-255)_{3}\end{array}$ & $\begin{array}{c}44.2 \pm 11.9 \\
(30.7-53.2)_{3}\end{array}$ & $\begin{array}{l}13.1 \pm 14.9 \\
(8.3-38.2)_{3}\end{array}$ & $\begin{array}{c}31.4 \pm 6.3 \\
(24.1-35.5)_{3}\end{array}$ & $\begin{array}{c}1.0 \pm 0.2 \\
(0.9-1.8)_{3}\end{array}$ & $\begin{array}{c}1.8 \pm 0.7 \\
(1.2-2.6)_{3}\end{array}$ & $\begin{array}{c}1.3 \pm 0.6 \\
(0.9-2.5)_{3}\end{array}$ & $\begin{array}{l}3.4 \pm 1.0 \\
(2.4-4.5)_{3}\end{array}$ \\
\hline Male & $\begin{array}{c}4.3 \pm 2.8 \\
(3-11)_{8}\end{array}$ & $\begin{array}{c}691 \pm 245 \\
(343-889)_{4}\end{array}$ & $\begin{array}{c}21.0 \pm 4.0 \\
(17.4-26.5)_{4}\end{array}$ & $\begin{array}{c}24.2 \pm 8.8 \\
(15.6-36.6)_{4}\end{array}$ & $\begin{array}{c}23.0 \pm 4.7 \\
4(19.7-29.8)_{4}\end{array}$ & $\begin{array}{c}1.6 \pm 0.2 \\
(1.4-1.8)_{4}\end{array}$ & $\begin{array}{c}1.6 \pm 0.3 \\
(1.2-1.9)_{4}\end{array}$ & $\begin{array}{c}1.6 \pm 0.2 \\
(1.2-1.9)_{4}\end{array}$ & $\begin{array}{l}12.3 \pm 12.0 \\
(2.3-27.5)_{4}\end{array}$ \\
\hline Total & $\begin{array}{l}5.6 \pm 2.9 \\
(3-11)_{16}\end{array}$ & $\begin{array}{c}489 \pm 306 \\
(195-889)_{7}\end{array}$ & $\begin{array}{c}40.0 \pm 14.4 \\
(17.4-53.2)_{7}\end{array}$ & $\begin{array}{l}23.7 \pm 10.7 \\
(8.3-38.2)_{7}\end{array}$ & $\begin{array}{c}26.6 \pm 6.7 \\
(19.7-35.5)_{7}\end{array}$ & $\begin{array}{l}1.4 \pm 0.5 \\
(0.9-1.8)_{7}\end{array}$ & $\begin{array}{c}1.7 \pm 0.4 \\
(1.2-2.6)_{7}\end{array}$ & $\begin{array}{c}1.5 \pm 0.4 \\
(0.9-2.5)_{7}\end{array}$ & $\begin{array}{c}8.5 \pm 9.7 \\
(2.3-27.5)_{7}\end{array}$ \\
\hline \multicolumn{10}{|l|}{ CDF } \\
\hline Female & $\begin{array}{c}4.9 \pm 1.4 \\
(3-7)_{10}\end{array}$ & $\begin{array}{c}768 \pm 402 \\
(577-1136)_{5}\end{array}$ & $\begin{array}{l}13.1 \pm 10.1 \\
(3.0-29.9)_{5}\end{array}$ & $\begin{array}{c}12.8 \pm 5.4 \\
(5.0-20.2)_{5}\end{array}$ & $\begin{array}{c}13.4 \pm 5.3 \\
(6.9-21.1)_{5}\end{array}$ & $\begin{array}{c}2.4 \pm 0.1 \\
(1.4-3.9)_{5}\end{array}$ & $\begin{array}{c}2.4 \pm 0.6 \\
(1.8-3.3)_{5}\end{array}$ & $\begin{array}{c}2.4 \pm 0.8 \\
(1.4-3.9)_{5}\end{array}$ & $\begin{array}{c}7.0 \pm 3.5 \\
(3.5-12.5)_{5}\end{array}$ \\
\hline Male & $\begin{array}{c}5.3 \pm 1.2 \\
(4-7)_{7}\end{array}$ & $\begin{array}{c}904 \pm 276 \\
(401-1305)_{5}\end{array}$ & $\begin{array}{c}26.8 \pm 8.0 \\
(18.7-39.7)_{5}\end{array}$ & $\begin{array}{c}23.9 \pm 8.1 \\
(10.6-33.3)_{5}\end{array}$ & $\begin{array}{c}25.1 \pm 6.6 \\
5(13.8-31.0)_{5}\end{array}$ & $\begin{array}{c}1.6 \pm 0.3 \\
(1.4-2.0)_{5}\end{array}$ & $\begin{array}{c}1.7 \pm 0.3 \\
(1.4-1.8)_{5}\end{array}$ & $\begin{array}{c}1.6 \pm 0.3 \\
(1.4-2.0)_{5}\end{array}$ & $\begin{array}{l}13.0 \pm 12.0 \\
(4.6-21.4)_{2}\end{array}$ \\
\hline Total & $\begin{array}{c}5.0 \pm 3.0 \\
(3-7)_{17}\end{array}$ & $\begin{array}{c}836 \pm 333 \\
(401-1305)_{10}\end{array}$ & $\begin{array}{c}20.0 \pm 11.3 \\
(3.0-39.7)_{10}\end{array}$ & $\begin{array}{c}18.4 \pm 8.7 \\
(5.0-33.3)_{10}\end{array}$ & $\begin{array}{c}19.2 \pm 8.4 \\
(6.9-31.0)_{10}\end{array}$ & $\begin{array}{c}2.0 \pm 0.6 \\
(1.4-3.9)_{10}\end{array}$ & $\begin{array}{c}2.0 \pm 1.0 \\
(1.4-3.3)_{10}\end{array}$ & $\begin{array}{c}2.0 \pm 0.8 \\
(1.4-3.9)_{10}\end{array}$ & $\begin{array}{c}8.7 \pm 6.4 \\
(3.5-21.4)_{7}\end{array}$ \\
\hline
\end{tabular}

was only weakly correlated with productivity $(\mathrm{r}=$ 0.03), the CDF distribution was correlated with a band of high productivity running east-west at $\sim 45^{\circ} \mathrm{S}(\mathrm{r}=$ 0.39) (Fig. 5).

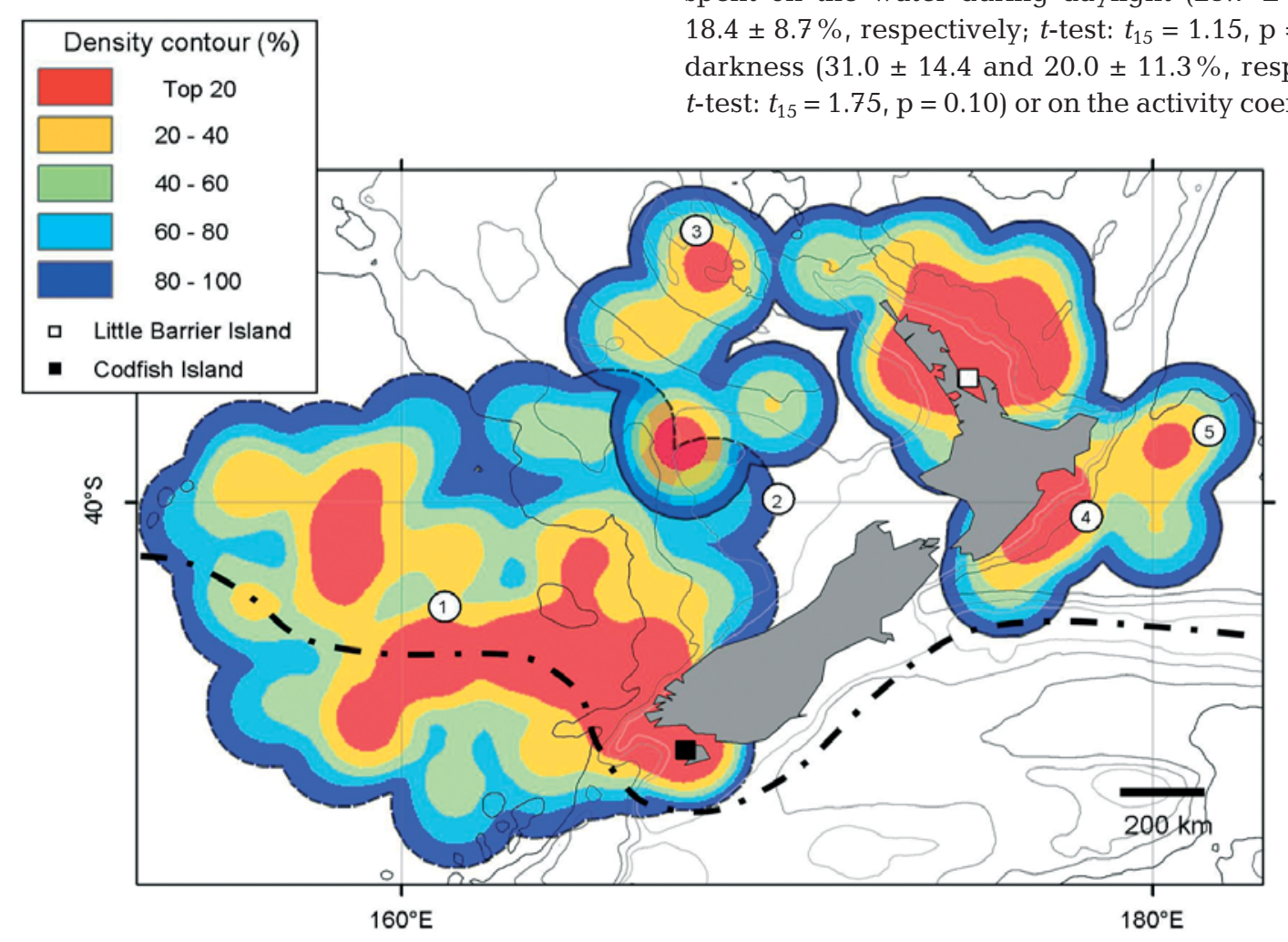

Fig. 2. Kernel density distribution of breeding Cook's petrel from Little Barrier Island ( $\mathrm{n}=7$, January 2007, enclosed by solid black line) and Codfish Island ( $\mathrm{n}=10$, February 2007, enclosed by dashed black line). Bathymetric contours are 500, 1000, 2000 and $4000 \mathrm{~m}$ (light grey to black). Numbers mark approximate locations of (1) Tasman Basin, (2) Challenger Plateau, (3) Lord Howe Rise, (4) Hikurangi Trough and (5) Hikurangi Plateau (derived from www.nabis.govt.nz). Heavy dot-dashed line: approximate summer location of Subtropical Convergence, based on Stanton \& Ridgeway (1988) and Orsi et al. (1995) 

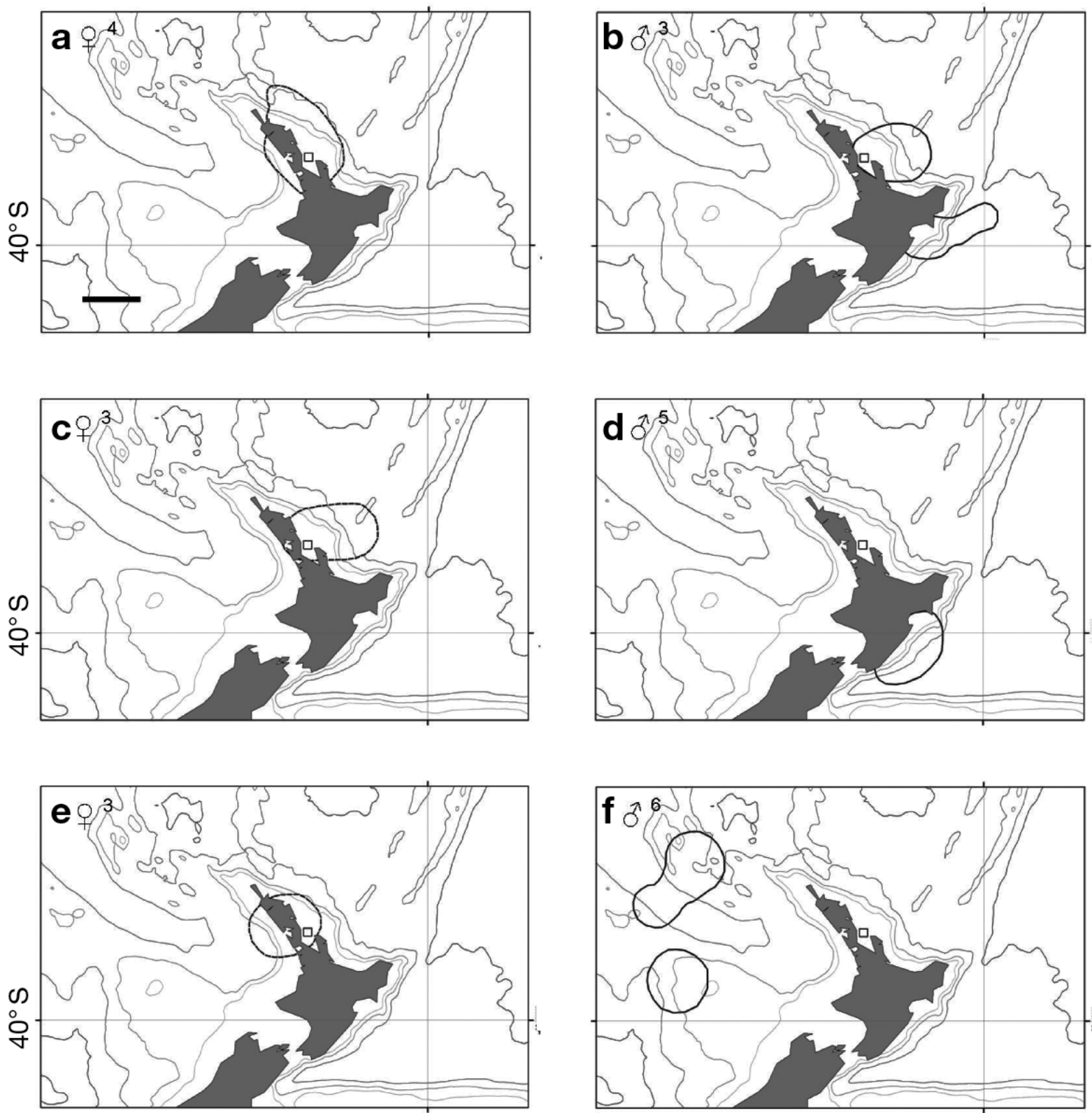

$180^{\circ} \mathrm{E}$

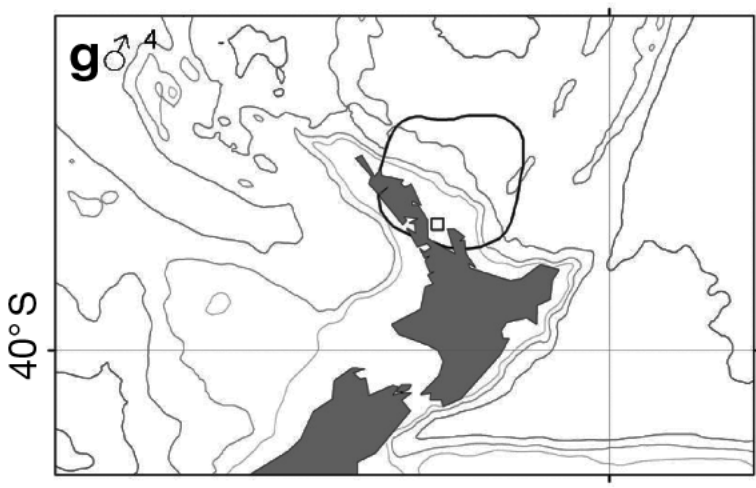

$180^{\circ} \mathrm{E}$

Fig. 3. Boundaries of $60 \%$ kernel density distributions for individual breeding Cook's petrel from Little Barrier Island overlaid on bathymetric contours. + Female $(\mathrm{a}, \mathrm{c}, \mathrm{e})$ and ${ }^{7}$ $(\mathrm{b}, \mathrm{d}, \mathrm{f}, \mathrm{g})$ male birds; superscripted numbers: foraging duration (days). Scale bar $=200 \mathrm{~km}$ 

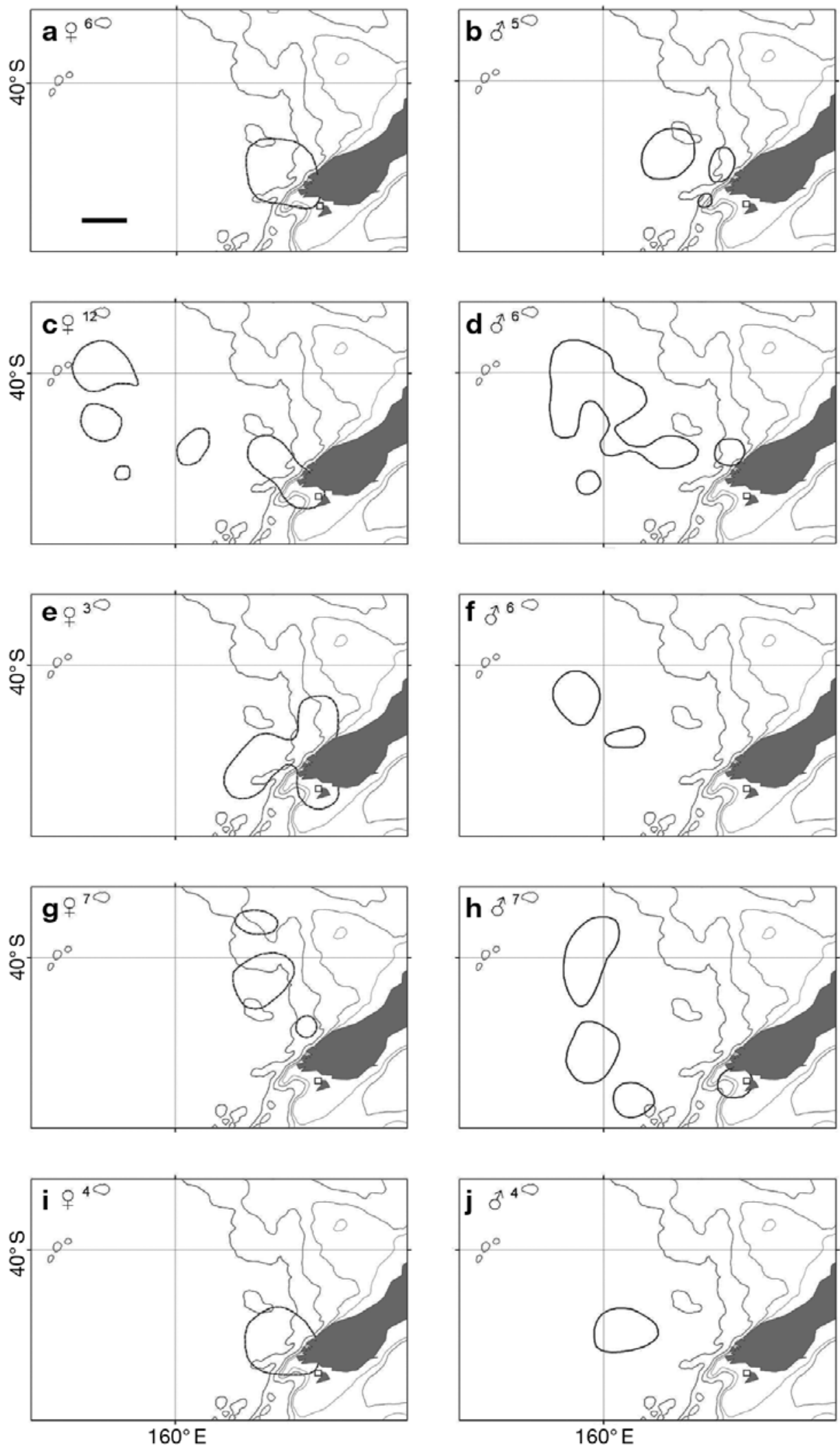

Fig. 4. Boundaries of $60 \%$ kernel density distributions for individual breeding Cook's petrel from Codfish Island overlaid on bathymetric contours. + Female $(\mathrm{a}, \mathrm{c}, \mathrm{e}, \mathrm{g}, \mathrm{i})$ and $\sigma^{7}$ male $(\mathrm{b}, \mathrm{d}, \mathrm{f}, \mathrm{h}, \mathrm{i})$ birds; superscripted numbers: foraging duration (days). 

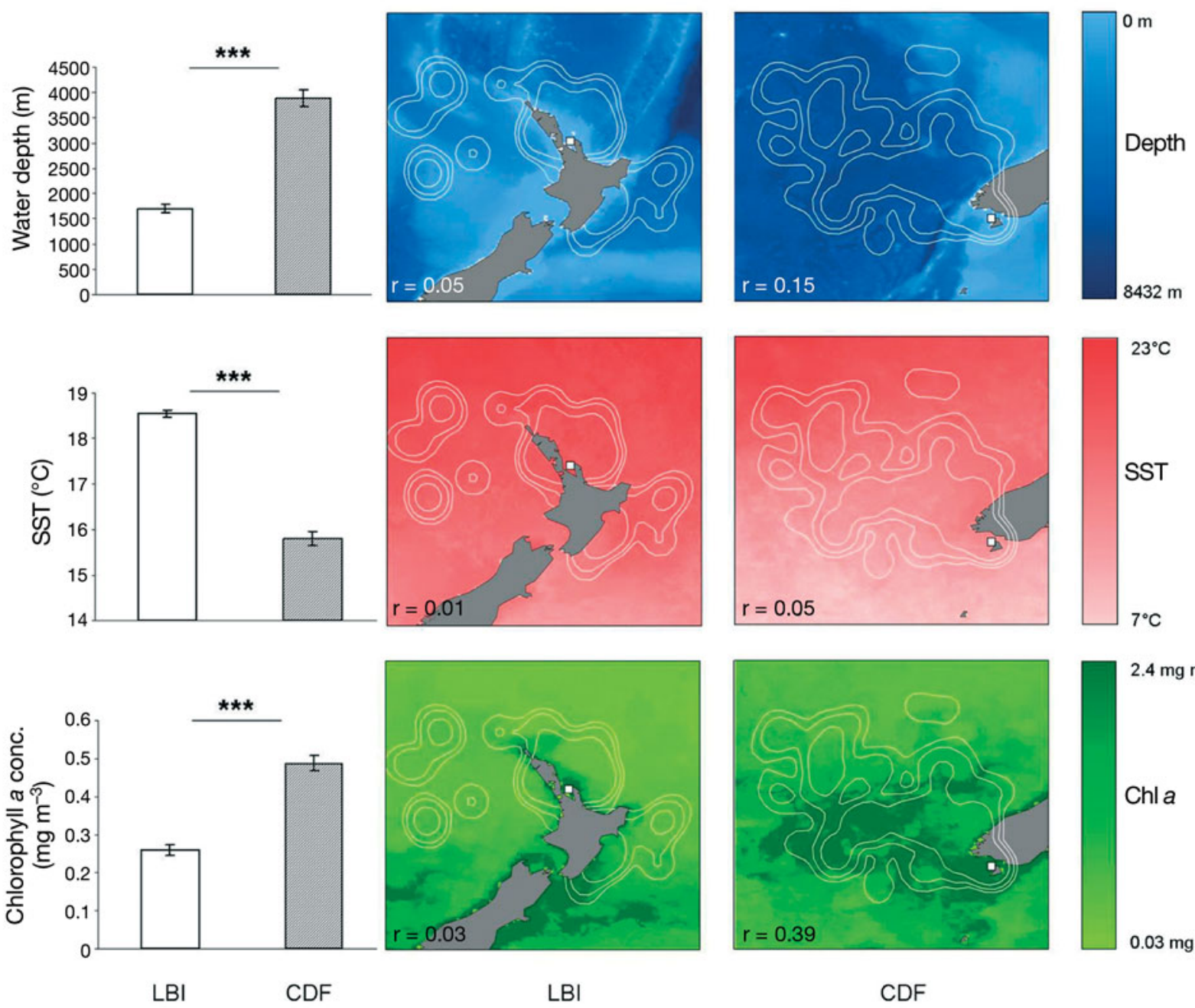

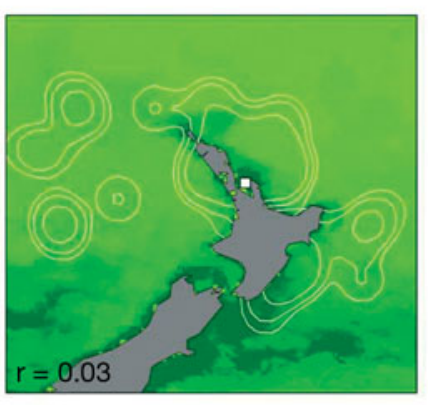

LBI

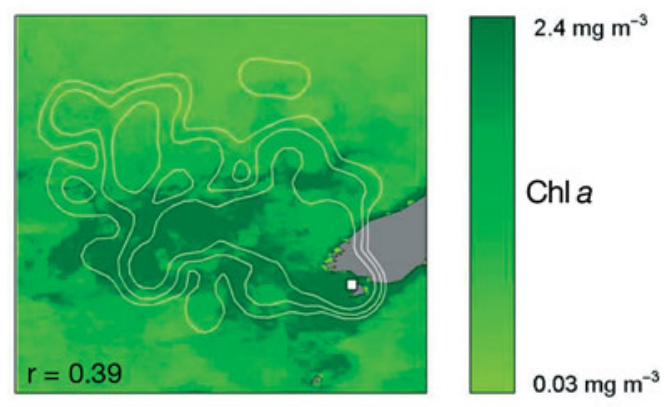

CDF

Fig. 5. Environmental characteristics of foraging distributions of Cook's petrels from Little Barrier Island (LBI, $\mathrm{n}=7$ ) and Codfish Island $(C D F, n=10)$. Graphs show differences in the average $( \pm S D)$ values for water depth, sea surface temperature (SST) and chl a concentration, extracted from the $60 \%$ kernels of each population distribution. ${ }^{* * *} \mathrm{p} \leq 0.001$ for difference from the logistic regression model. Coloured panels show degree of correlation between the $60 \%$ kernel density distribution for each population and underlying environmental parameters

variation $(\mathrm{CV})$ during daylight $(1.7 \pm 0.4$ and $2.0 \pm 1.0$, respectively; $t$-test: $\left.t_{15}=1.50, \mathrm{p}=0.16\right)$ or darkness $(1.4$ \pm 0.5 and $2.0 \pm 0.6$, respectively; $t$-test: $t_{15}=1.30, \mathrm{p}=$ 0.23) (Table 1). However, within each $24 \mathrm{~h}$ period, (data combined), birds from LBI spent a higher percentage of their time on the water ( $t$-test: $t_{15}=2.01, \mathrm{p}=0.03$; Fig. 6a) and displayed less immersion variation ( $t$-test: $t_{15}=-2.75, \mathrm{p}<0.01$; Fig. 6b). They also had smaller maximum foraging ranges than those from CDF ( $t$-test: $\left.t_{15}=-2.22, \mathrm{p}=0.02\right)$, but travelled similar distances per day whilst at sea ( $t$-test: $t_{15}=-0.84, \mathrm{p}=0.10$ ) (Table 1 ). There was considerable variation in maximum dive depth, which ranged from 2 to $27 \mathrm{~m}$ and from 3 to $21 \mathrm{~m}$ for birds from LBI and CDF, respectively, but there was no significant difference in the mean for each colony $(8.5 \pm 3.9 \mathrm{~m}, \mathrm{n}=7$, and $8.7 \pm 2.4 \mathrm{~m}, \mathrm{n}=7$, respectively; $t$-test: $t_{12}=-0.68, \mathrm{p}=0.26$; Table 1$)$. Nor was there any obvious sex-related differences in any behavioural parameter at either colony (Table 1), although small sample sizes prevented statistical testing.

\section{Stable isotopes}

A total of 12 blood samples were collected from Cook's petrels returning to LBI with loggers $(n=7)$ or depth gauges $(\mathrm{n}=5)$, and 11 blood samples from Cook's petrel returning to CDF with loggers $(n=10)$ or depth gauges $(n=1)$. There was a significant difference in mean blood $\delta^{15} \mathrm{~N}$ between adults at LBI $(12.8 \pm$ $0.5)$ compared with $\mathrm{CDF}(11.7 \pm 0.5)\left(t\right.$-test: $t_{21}=-5.14$, $\mathrm{p}<0.001$ ), but not in mean blood $\delta^{13} \mathrm{C}$ values (means of 

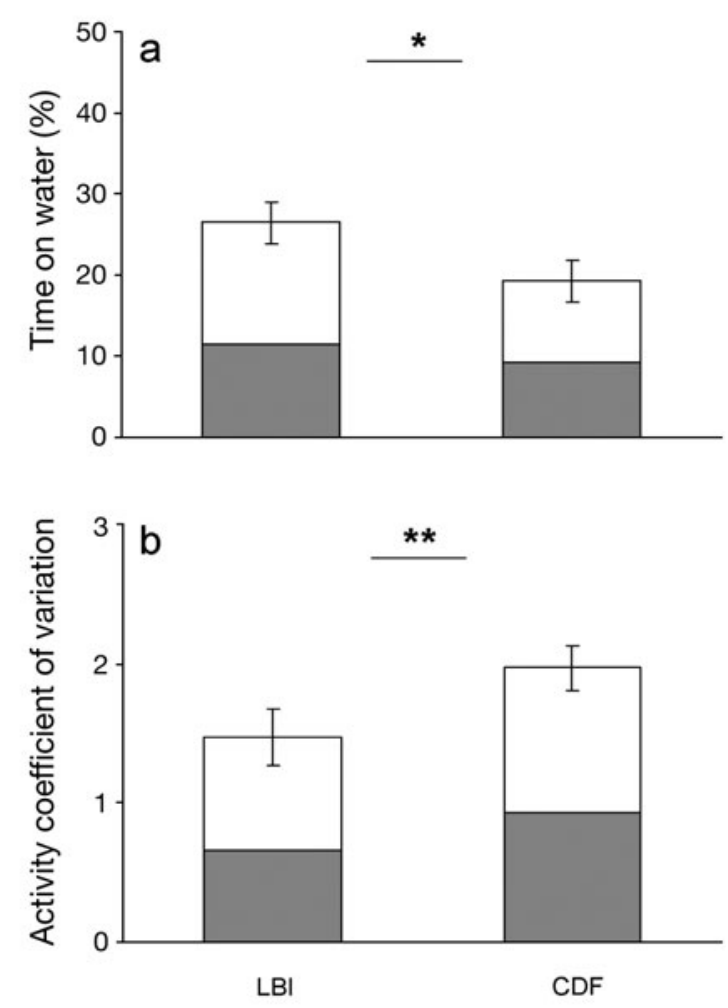

Fig. 6. Daily foraging activity of Cook's petrel tracked from Little Barrier Island (LBI) and Codfish Island (CDF) showing (a) percentage of time spent on the water $( \pm \mathrm{SD})$ and $(\mathrm{b})$ variation in immersion activity $( \pm \mathrm{SD})$. White and grey bar components represent daytime and nighttime contributions to activity variable, respectively. ${ }^{*} \mathrm{p}<0.05,{ }^{* *} \mathrm{p}<0.01$

$18.4 \pm 0.4$ and $18.6 \pm 0.4$ for LBI and CDF, respectively; $t$-test, $t_{21}=-0.45, \mathrm{p}=0.66$ ) (Fig. 7). There was no significant difference between the isotope ratios of birds with loggers $\left(\delta^{15} \mathrm{~N}=12.6 \pm 0.3, \delta^{13} \mathrm{C}=-18.9 \pm 0.3\right)$ rather than depth gauges $\left(\delta^{15} \mathrm{~N}=13.0 \pm 0.4, \delta^{13} \mathrm{C}=\right.$ $-18.6 \pm 0.7)$ at LBI ( $t$-test, $t_{11}=-1.48, \mathrm{p}=0.18$ for $\delta^{15} \mathrm{~N}$, and $t_{11}=1.38, \mathrm{p}=0.20$ for $\delta^{13} \mathrm{C}$ ), indicating that device type had no discernable effect upon prey selection. There was no effect of sex on stable isotope values at LBI $\left(\delta^{15} \mathrm{~N}\right.$ in females $=12.7 \pm 0.3$, in males $=12.8 \pm 0.4$, $t$-test, $t_{10}=0.54, \mathrm{p}=0.60 ; \delta^{13} \mathrm{C}$ in females $=-18.52 \pm 0.5$, in males $=-18.30 \pm 0.4, t$-test, $t_{10}=1.08, \mathrm{p}=0.30$ ) or $\mathrm{CDF}\left(\delta^{15} \mathrm{~N}\right.$ in females $=11.5 \pm 0.6$, in males $=11.8 \pm 0.5$, $t$-test, $t_{9}=0.55, \mathrm{p}=0.60 ; \delta^{13} \mathrm{C}$ in females $=-18.7 \pm 0.5$, in males $=-18.3 \pm 0.2, t$-test, $t_{9}=1.48, \mathrm{p}=0.17$ ).

\section{Chick provisioning}

The mean meal mass fed to chicks at CDF (37.9 \pm $6.7 \mathrm{~g})$ was higher on average than at LBI $(36.8 \pm 4.0 \mathrm{~g})$, although the difference was non-significant ( $t$-test: $t_{19}=-1.24, \mathrm{p}=0.81$ ) (Fig. 8a). However, mean daily

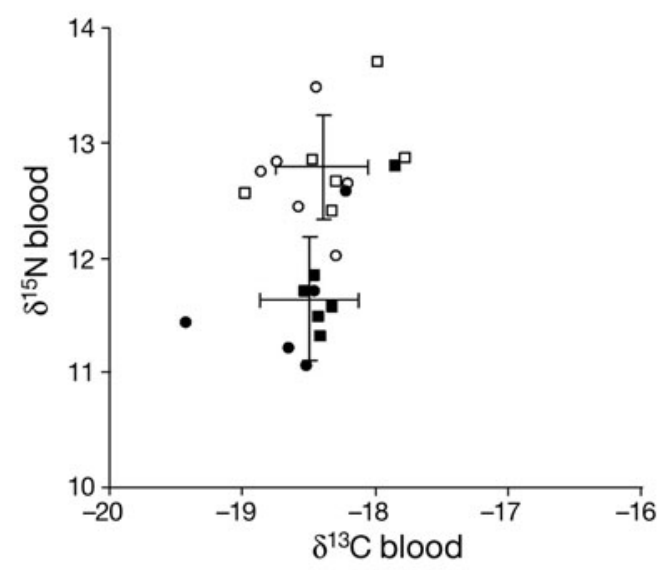

Fig. 7. Stable isotope signatures in the blood of Cook's petrel during early chick-rearing at Little Barrier Island $(\mathrm{O}=$ male, $\square=$ female, $\mathrm{n}=12)$ and Codfish Island $(\bullet=$ male, $\mathbf{\square}=$ female, $\mathrm{n}=11$ )

food delivery ( $g$ night $^{-1}$ ) over the length of each study period was significantly greater for chicks at CDF $\left(13.2 \pm 1.0 \mathrm{~g} \mathrm{night}^{-1}\right)$ than at LBI $\left(10.0 \pm 1.2 \mathrm{~g} \mathrm{night}^{-1}\right)$ ( $t$-test: $t_{18}=-2.45, \mathrm{p}=0.01$ ) (Fig. $8 \mathrm{~b}$ ), presumably reflecting the greater mean meal mass and shorter foraging trip durations at this colony.
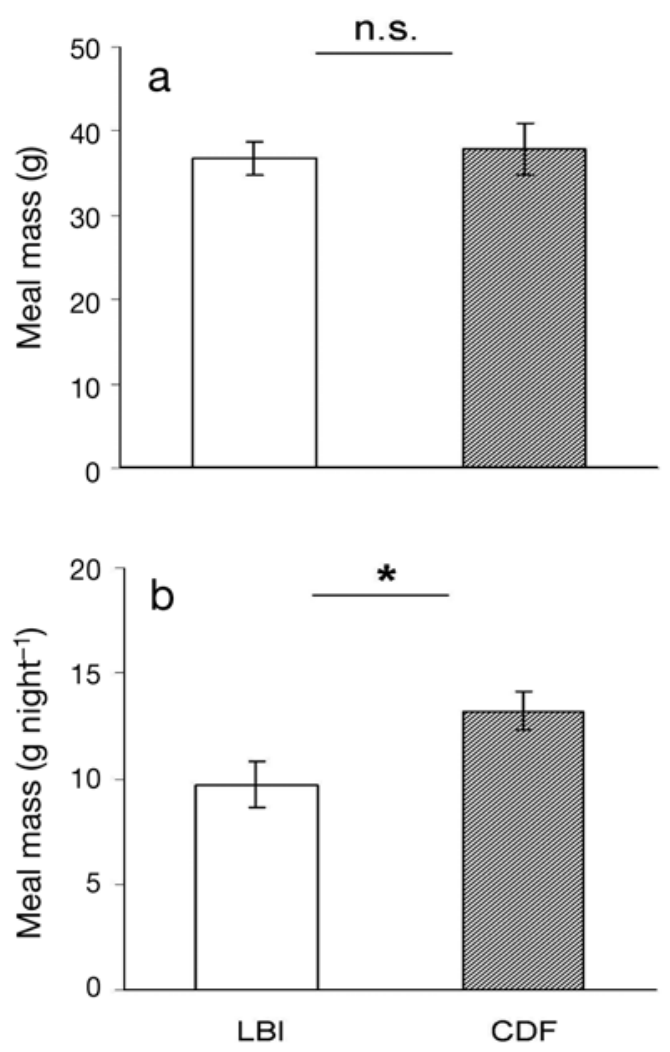

Fig. 8. Provisioning rate of Cook's petrels. (a) Mean meal mass $( \pm \mathrm{SD})$ and (b) daily food delivery $( \pm \mathrm{SD})$ over the $14 \mathrm{~d}$ study period at Little Barrier Island (LBI) and Codfish Island (CDF). n.s. = not significant. ${ }^{*} \mathrm{p}<0.05$ 


\section{DISCUSSION}

This study presents the first detailed analysis of the foraging behaviour and ecology of a small petrel $(<300 \mathrm{~g})$ using geolocation technology with key findings relating to the spatial, behavioural and dietary segregation of the 2 major and geographically distant Cook's petrel populations. Despite the low precision of the geolocators used (mean accuracy \pm SD, $186 \pm$ $114 \mathrm{~km}$; Phillips et al. 2004), the spatial segregation of foraging ranges of Cook's petrel during chick provisioning was sufficient to be captured using these devices. Previous investigation demonstrated no discernible impacts of heavier geolocators than those used in the present study on the foraging duration and provisioning rate of Cook's petrel (Rayner 2007). In addition, comparison of foraging trip durations and isotope values between birds fitted with loggers compared with depth gauges showed no apparent effects. There is therefore no reason to suspect that the foraging behaviour observed during the present study was unrepresentative. A weakness of the present study, however, was its temporal scope. The study was designed to focus on the same breeding stage of the adult birds by comparing data on pairs with similar developmental stages of chicks. Yet, the foraging strategies of petrels often change with breeding stage (Warham 1990, Weimerskirch et al. 1993, 1997) and so caution must be advised in assuming that birds from the 2 populations show as distinctive distributions or behaviour at other times of the season or in other years.

\section{Foraging distribution and duration}

Colony-specific foraging areas have been widely documented in studies of seabirds (Ainley et al. 2003, 2004, Peck \& Congdon 2005), and ecological theory predicts that density-dependent competition drives this spatial segregation because of the fitness advantages of feeding closer to the nest site (Ashmole 1963, Diamond 1978). In the present study the foraging distributions of tracked Cook's petrel were highly segregated, overlapping only at the periphery of their respective distributions at $\sim 38^{\circ} \mathrm{S}$ (Fig. 2). Cook's petrels from LBI foraged east and west of the North Island over the continental shelf, shelf break and pelagic waters, in a distribution that was not closely associated with particular environmental parameters (depth, SST and chl a). By comparison, Cook's petrel from CDF foraged west of the South Island in the Tasman Sea, primarily away from the continental shelf. The 2 populations could be clearly separated by habitat: birds from CDF on average foraged over deeper (3789 m, cf. LBI: 1887$)$, cooler water $\left(15.8^{\circ} \mathrm{C}\right.$, cf. LBI: $\left.18.5^{\circ} \mathrm{C}\right)$ with higher $\mathrm{chl}$ a concentration $\left(0.48 \mathrm{mg} \mathrm{m}^{-3}\right.$, cf. LBI: $0.26 \mathrm{mg} \mathrm{m}^{-3}$ ) than those from LBI (Fig. 5). Close association between the core range of Cook's petrel from CDF and high chl a concentrations in the Tasman Sea subtropical convergence, where enhanced vertical mixing of warm and cool water masses promotes increased surface nutrient levels and high level of primary productivity (Orsi et al. 1995), is particular noteworthy.

Density-dependent competition related to colony size is usually considered to be a key determinant of foraging distribution and behaviour. Positive relationships between colony size and area of foraging grounds, maximum foraging range, foraging trip duration and provisioning rate have been demonstrated in a range of colonial seabirds, with resource depletion and increased interference competition close to the colonies assumed to be driving this process (Lewis et al. 2001, Ainley et al. 2003, 2004). Data for Cook's petrel are inconsistent with this hypothesis, as maximum foraging ranges of birds at LBI were significantly shorter than those at $\mathrm{CDF}$, despite a population size 50 times greater (286000 breeding pairs at LBI vs. 6000 breeding pairs at CDF; Rayner et al. 2007C, 2008). Two non-exclusive explanations could account for this discrepancy. First, the Tasman Sea likely experiences more consistent wind velocities than the east coast of the North Island as a result of the predominantly west to southwest winds generated by subantarctic weather systems (Richard et al. 2005). Higher wind speeds improve flight efficiency and speed in procellariiformes (Warham 1996). This would reduce travel costs for Cook's petrel from CDF, allowing them to actively target a spatially discrete, and geographically distant, foraging area at the mid-Tasman subtropical convergence. Similarly, other procellariiformes, including Buller's albatross Thalassarche bulleri, forage close to the Tasman Sea subtropical convergence during the breeding season, presumably also exploiting the enhanced food resources in this highly productive zone (Stahl \& Sagar 2000a,b).

A range of studies demonstrated the use of 2-fold foraging strategies in procellariiformes during chickrearing, with adults alternating between short trips, to provision chicks, and long trips, to maintain their own body condition (Weimerskirch et al. 1997, Cherel et al. 2002a, Peck \& Congdon 2005). The evidence for a bimodal foraging strategy in either Cook's petrel population in the present study was inconclusive, suggesting that during the early phase of chick-rearing, foraging resources may be sufficient to allow breeding birds to provision chicks and maintain their own physiological requirements. However, the duration of the present study may have been insufficient to capture the complete range of trip durations, particularly if the fre- 
quency of long trips was lower than shorter trips. As a result, caution should be exercised in concluding a lack of bimodal foraging in Cook's petrel during breeding.

\section{Foraging behaviour}

In addition to divergent spatial distributions and range characteristics, Cook's petrel from LBI and CDF exhibited different patterns of foraging activity. Birds from CDF spent more time in flight than those from LBI, consistent with their greater foraging ranges, which we suggest might be facilitated by the more favourable and predictable weather conditions in the south Tasman Sea. However, the difference could also relate to diet selection and whether birds predominantly search for prey in flight or sit on the water and ambush prey that come to the surface, which may be much more effective at night (Catry et al. 2004, Phalan et al. 2007). As a result of technological limitations, previous studies investigating the foraging activity of seabirds focused on larger species with very different circadian activity patterns. For example, during the same breeding stage (post-brood chick-rearing), albatrosses spend much more time overall than Cook's petrel ( 31 to $55 \%$ vs. $20 \%$ for Cook's petrel) and a higher percentage of darkness on the water ( $\sim 7$ to $90 \%$ vs. $10 \%$ for Cook's petrel) (Phalan et al. 2007). The difference most likely reflects the relative advantage of the alternative foraging strategies outlined above ('Foraging distribution and duration'). Albatrosses have a reduced ability to see and capture prey from the air at night (Weimerskirch et al. 1994, 2005, Phalan et al. 2007), whereas our data strongly suggest that Cook's petrel is a highly active nocturnal forager.

Cook's petrels lack the aquatic features of diving shearwaters (Puffinus spp.) such as compact plumage and compressed tarsi, and are thus considered to feed mainly on prey floating near the surface (Warham 1990, Brooke 2004). However, although not as deepdiving as common diving petrels Pelecanoides urinatrix (mean $30 \mathrm{~m}$ ) (Bocher et al. 2000), the maximum dive depths recorded in the birds in the present study (mean $8 \mathrm{~m}$, max. $27.5 \mathrm{~m}$ ) were deeper than those of other small petrels, including Bulwer's petrel Bulweria bulwerii (mean 2 to $3 \mathrm{~m}$, max. $5 \mathrm{~m}$ ) (Mougin \& Mougin 2000), blue petrel Halobaena caerulea (mean $4.4 \mathrm{~m}$, max. 6 m) (Cherel et al. 2002b), but not as deep as the considerably larger wedge-tailed shearwater Puffinus pacificus (mean 14.0 m, max. 66.0 m) (Burger 2001), Audubon's shearwater Puffinus lherminieri (average $15.0 \mathrm{~m}$, max. $35.0 \mathrm{~m}$ ) (Burger 2001) and sooty shearwater Puffinus griseus (average $14.2 \mathrm{~m}$, max. $68.2 \mathrm{~m}$ ) (Shaffer et al. 2006). This suggests a greater reliance on pursuit diving in the Cook's petrel than previously thought and indicates that morphological characteristics may not always be indicative of diving ability in procellariiformes.

Carbon isotope values provide an indication of foraging latitude (lower $\delta^{13} \mathrm{C}$ values at higher latitudes) and the degree of pelagic (off-shelf) versus inshore foraging (higher $\delta^{13} \mathrm{C}$ values in species that forage in inshore environments) (Cherel et al. 2000, Thompson et al. 2000, Quillfeldt et al. 2005). That $\delta^{13} \mathrm{C}$ signatures for Cook's petrel from LBI and CDF are similar is presumably because birds from both colonies foraged in relatively deep subtropical waters. Significant differences in the $\delta^{15} \mathrm{~N}$ signatures, however, indicate some degree of dietary specialisation (Fig. 7), with adults from LBI apparently including a larger component of higher trophic-level prey than those from CDF. Imber (1996) found the diet of Cook's petrel from LBI to be comprised, in order of importance, of cephalopoda (squid species), fish, crustaceans (krill species) and tunicates. Although the diet of Cook's petrel at CDF is unknown, cephalopods ( $\delta^{15} \mathrm{~N}$ : 8.1 to $10.2 \%$ ) and fish $\left(\delta^{15} \mathrm{~N}\right.$ : 7.5 to $10.9 \%$ ) (Burns et al. 1998, Cherel et al. 2000, Kaehler et al. 2000) occupy a higher trophic level than marine crustaceans ( $\delta^{15} \mathrm{~N}$ : 3.6 to $6.5 \%$ ) (Thompson \& Furness 1995, Cherel et al. 2002b). Accordingly, the differences in $\delta^{15} \mathrm{~N}$ suggest that Cooks' petrel from LBI consume more cephalopods and fish and fewer crustaceans than those from CDF.

Regional differences in oceanic productivity and thus food availability to breeding birds have led to a divergence in foraging and provisioning strategies among different colonies of a variety of seabirds (Stahl \& Sagar 2000a,b, Ainley et al. 2004, Walker \& Elliot 2006). The results of the present study suggest the same applies to Cook's petrel. Combining information on distribution, at-sea activity and stable isotope signatures suggests that during chick-rearing, Cook's petrel from CDF took advantage of potentially more favourable winds to target abundant, lower trophiclevel prey found in association with the Tasman Sea subtropical convergence. By comparison, Cook's petrel from LBI foraged more widely in the Tasman Sea and Pacific Ocean and targeted a broader array of dietary components including crustaceans, squid and fish. Future research should focus on whether these differences in foraging distribution and behaviour persist throughout the year, and also on an investigation of the levels of genetic variation and degree of reproductive isolation between these distant colonies, particularly given the difference in breeding phenology.

Acknowledgements. We thank the New Zealand Department of Conservation staff from the Auckland (S. Cameron, S. McInnis, R. Renwick and L. Whitwell) and Southern Islands 
(T. Lawrence, P. McClelland, D. Vercoe and D. Veint) Conservancies for facilitating access to conduct this research, and for assistance and support. We are indebted to $\mathrm{M}$. Le Corre, S. Bartle, B. Dunphy, M. Imber and 2 anonymous referees for improving the manuscript, and acknowledge essential research funding by the Little Barrier Island Supporters Trust, through an ASB Bank Community Trust grant, and by the University of Auckland, through the Faculty of Science Professional Development Fund and School of Biological Sciences performance-based research fund. M.J.R. was supported by a New Zealand Tertiary Education Commission Top Achiever Doctoral Scholarship. This research was conducted with ethics approval from the University of Auckland Animal Ethics Committee and research permission from the New Zealand Department of Conservation.

\section{LITERATURE CITED}

Afanasyev V (2004) A miniature daylight level and activity data recorder for tracking animals over long periods. Mem Natl Inst Polar Res 58(Spec Issue):227-233

Ainley DG, Ford RG, Brown ED, Suryan RM, Irons DB (2003) Prey resources, competition, and geographic structure of kittiwake colonies in Prince William Sound. Ecology 84: 709-723

Ainley DG, Ribic CA, Ballard G, Heath S and others (2004) Geographic structure of Adélie penguin populations: overlap in colony-specific foraging areas. Ecol Monogr 74: 159-178

Ashmole NP (1963) The regulation of numbers of tropical oceanic seabirds. Ibis 103b:458-473

Bartle JA, Hu D, Stahl JC, Pyle P, Simons TR, Woodby D (1990) Status and ecology of gadfly petrels in the temperate north Pacific. In: Vermeer K, Briggs KT, Morgan KH, Siegel-Causey D (eds) The status, ecology, and conservation of marine birds of the North Pacific. Canadian Wildlife Service Special Publication, Ottawa, p 101-111

Bearhop S, Waldron S, Votier SC, Furness RW (2002) Factors that influence assimilation rates and fractionation of nitrogen and carbon stable isotopes in avian blood and feathers. Physiol Biochem Zool 75:451-458

Behrenfeld MJ, Falkowski PG (1997) Photosynthetic rates derived from satellite-based chlorophyll concentration. Limnol Oceanogr 42:1-20

> Bocher P, Cherel Y, Hobson KA (2000) Complete trophic segregation between South Georgian and common diving petrels during breeding at Iles Kerguelen. Mar Ecol Prog Ser 208:249-264

Brooke MDL (2004) Albatrosses and petrels across the world. Oxford University Press, Oxford

Burger AE (2001) Diving depths of shearwaters. Auk 118: 755-759

Burger AE, Wilson RP (1988) Capillary-tube depth gauges for diving animals: an assessment of their accuracy and applicability. J Field Ornithol 59:345-354

Burns JM, Trumble SJ, Castellini MA, Testa JW (1998) The diet of Weddell seals in McMurdo Sound, Antarctica as determined from scat collections and stable isotope analysis. Polar Biol 19:272-282

> Catry P, Phillips RA, Phalan B, Silk JRD, Croxall JP (2004) Foraging strategies of grey-headed albatross Thalassarche chrysostoma: integration of movements, activity and feeding events. Mar Ecol Prog Ser 280:261-273

Cherel Y, Hobson KA, Weimerskirch H (2000) Using stableisotope analysis of feathers to distinguish moulting and breeding origins of seabirds. Oecologia 122:155-162
Cherel Y, Bocher P, De Broyer C, Hobson KA (2002a) Food and feeding ecology of the sympatric thin-billed Pachyptila belcheri and Antarctic P. desolata prions at Iles Kerguelan, Southern Indian Ocean. Mar Ecol Prog Ser 228:263-281

> Cherel Y, Bocher P, Trouvé C, Weimerskirch H (2002b) Diet and feeding ecology of blue petrels Halobaena caerulea at Iles Kerguelen, Southern Indian Ocean. Mar Ecol Prog Ser 228:283-299

Diamond AW (1978) Feeding strategies and population size in tropical seabirds. Am Nat 112:215-224

Fridolfsson AK, Ellegren H (1999) A simple and universal method for molecular sexing of non-ratite birds. J Avian Biol 30:116-121

> Hamer KC, Nicholson LW, Hill JK, Wooller RD, Bradley JS (1997) Nestling obesity in procellariiform seabirds: temporal and stochastic variation in provisioning and growth of short-tailed shearwaters Puffinus tenuirostris. Oecologia 112:4-11

> Hobson KA (1993) Trophic relationships among high Arctic seabirds: insights from tissue-dependent stable-isotope models. Mar Ecol Prog Ser 95:7-18

> Hobson KA, Piatt JF, Pitocchelli J (1994) Using stable isotopes to determine seabird trophic relationships. J Anim Ecol 63: $786-798$

Imber MJ (1996) The food of Cook's petrel Pterodroma cookii during its breeding season on Little Barrier Island, New Zealand. Emu 96:189-194

Imber MJ, West JA, Cooper WJ (2003) Cook's petrel (Pterodroma cookii): historic distribution, breeding biology, and effects of predators. Notornis 50:221-230

> Kaehler S, Pakhomov EA, McQuaid CD (2000) Trophic structure of the marine food web at the Prince Edward Islands (Southern Ocean) determined by $\delta^{13} \mathrm{C}$ and $\delta^{15} \mathrm{~N}$ analysis. Mar Ecol Prog Ser 208:13-20

> Lewis S, Sherratt TN, Hamer KC, Wanless S (2001) Evidence of intra-specific competition for food in a pelagic seabird. Nature 412:816-819

> Mougin JL, Mougin MC (2000) Maximum diving depths for feeding attained by Bulwer's petrels (Bulweris bulwerii) during the incubation period. J Zool 250:75-77

Onley D, Scofield P (2007) Albatrosses, petrels \& shearwaters of the world. Princeton University Press, Princeton, NJ

Orsi AH, Whitworth T, Nowlin WD (1995) On the meridional extent and fronts of the Antarctic Circumpolar Current. Deep-Sea Res Part I 42:641-673

Patterson DL, Hunter S (2000) Giant petrel Macronectes spp. band recovery analysis from the International Giant Petrel Banding Project, 1988/89. Mar Ornithol 28:69-74

Peck DR, Congdon BC (2005) Colony-specific foraging behaviour and co-ordinated divergence of chick development in the wedge-tailed shearwater Puffinus pacificus. Mar Ecol Prog Ser 299:289-296

Phalan B, Phillips RA, Silk JRD, Afanasyev V and others (2007) Foraging behaviour of four albatross species by night and day. Mar Ecol Prog Ser 340:271-286

Phillips RA, Silk JRD, Croxall JP, Afanasyev V, Briggs DR (2004) Accuracy of geolocation estimates for flying seabirds. Mar Ecol Prog Ser 266:265-272

Phillips RA, Silk JRD, Croxall JP (2005) Foraging and provisioning strategies of the light-mantled sooty albatross at South Georgia: competition and co-existence with sympatric pelagic predators. Mar Ecol Prog Ser 285:259-270

> Phillips RA, Silk JRD, Croxall JP, Afanasyev V (2006) Yearround distribution of white-chinned petrels from South Georgia: relationships with oceanography and fisheries. Biol Conserv 129:336-347 
Phillips RA, Catry P, Silk JRD, Bearhop S, McGill R, Afanasyev V, Strange IJ (2007) Movements, winter distribution and activity patterns of Falkland and brown skuas: insights from loggers and isotopes. Mar Ecol Prog Ser 345: 281-291

Prince PA, Jones M (1992) Maximum dive depths attained by South Georgia diving petrel Pelecanoides georgicus at bird island South Georgia. Antarct Sci 4:433-434

Quillfeldt P, McGill RA, Furness RW (2005) Diet and foraging areas of Southern Ocean seabirds and their prey inferred from stable isotopes: review and case study of Wilson's storm-petrel. Mar Ecol Prog Ser 295:295-304

Rayner MJ (2007) Effects of dummy global location sensors on foraging behaviour of Cook's petrel (Pterodroma cookii). Wilson J Ornithol 119:109-111

Rayner MJ, Hauber ME, Clout MN (2007a) Breeding habitat of the Cook's petrel (Pterodroma cookii) on Little Barrier Island (Hauturu): implications for the conservation of a New Zealand endemic. Emu 107:59-68

Rayner MJ, Hauber ME, Imber MJ, Stamp RK, Clout MN (2007b) Spatial heterogeneity of mesopredator release within an oceanic island system. Proc Natl Acad Sci USA 104:20862-20865

Rayner MJ, Clout MN, Stamp RK, Imber MJ, Brunton DH, Hauber ME (2007c) Predictive habitat modelling improves the population census accuracy of a burrowing seabird: a study of the endangered Cook's petrel. Biol Conserv 138: 235-247

Rayner MJ, Parker KA, Imber MJ (2008) Population census of Cook's petrel Pterodroma cookii breeding on Codfish Island (New Zealand) and the global conservation status of the species. Bird Conserv Int 18:211-218

Richard GJ, Hadfield MG, Roberts MJ (2005) Development of a regional ocean model for New Zealand. N Z J Mar Freshw Res 39:1171-1191

Shaffer SA, Tremblay Y, Weimerskirch H, Scott D and others (2006) Migratory shearwaters integrate oceanic resources across the Pacific Ocean in an endless summer. Proc Natl Acad Sci USA 103:12799-12802

Editorial responsibility: Matthias Seaman, Oldendorf/Luhe, Germany
Stahl JC, Sagar PM (2000a) Foraging strategies and migration of southern Buller's albatrosses Diomedea bulleri breeding on the Solnder Is, New Zealand. J R Soc N Z 30: 319-334

Stahl JC, Sagar PM (2000b) Foraging strategies of southern Buller's albatrosses Diomedea bulleri breeding on the Snares, New Zealand. J R Soc N Z 30:299-318

Stanton BR, Ridgeway NM (1988) An oceanographic survey of the subtropical convergence zone in the Tasman Sea. N Z J Mar Freshw Res 22:583-593

Thompson DR, Furness RW (1995) Stable-isotope ratios of carbon and nitrogen indicate seasonal dietary shifts in northern fulmars. Auk 112:493-498

Thompson DR, Phillips RA, Stewart FM, Waldron S (2000) Low $\delta^{13} \mathrm{C}$ in pelagic seabirds: lipid ingestion as a potential source of ${ }^{13} \mathrm{C}$-depleted carbon in Procellariiformes. Mar Ecol Prog Ser 208:265-271

Walker K, Elliot G (2006) At-sea distributions of Gibson's and Antipodean wandering albatrosses, and relationships with longline fisheries. Notornis 53:265-290

Warham J (1990) The petrels their ecology and breeding systems. Academic Press, London

Warham J (1996) The behaviour, population biology and physiology of the petrels. Academic Press, London

Weimerskirch H, Salamolard M, Sarrazin F, Jouventin M (1993) Foraging strategies of wandering albatrosses throughout the breeding season, a study using satellite telemetry. Auk 110:325-342

Weimerskirch H, Chastel O, Ackermann L, Chaurand T, Cuenot-Chaillet F, Hindermeyer X, Judas J (1994) Alternate long and short foraging trips in pelagic seabird parents. Anim Behav 47:472-476

Weimerskirch H, Cherel Y, Cuenot-Chaillet F, Ridoux V (1997) Alternative foraging strategies and resource allocation by male and female wandering albatrosses. Ecology 78:2051-2063

Weimerskirch H, Gault A, Cherel Y (2005) Prey distribution and patchiness: factors in foraging success and efficiency of wandering albatross. Ecology 86:2611-2622

Submitted: May 13, 2008; Accepted: July 22, 2008 Proofs received from author(s): October 20, 2008 